\title{
Visualization of Endogenous Glycine in Cat Retina: An Immunocytochemical Study with Fab Fragments
}

\author{
Roberta G. Pourcho and Dennis J. Goebel \\ Department of Anatomy and Cell Biology, School of Medicine, Wayne State University, Detroit, Michigan 48201
}

\begin{abstract}
Fab fragments of a glycine antiserum were prepared and used for immunocytochemical visualization of glycine in the cat retina. The use of Fab fragments in conjunction with Fab-specific secondary and tertiary antisera improved tissue penetration and made it possible to identify a number of the immunoreactive neurons. Staining was observed in several subpopulations of amacrine cells, including the A7(All) rod amacrine. Multiple subpopulations of cone bipolar cells were also seen to be immunoreactive. Many neurons exhibited no detectable immunostaining, indicating that general metabolic levels of glycine do not interfere with the visualization of those cells that contain large amounts of endogenous glycine. The distribution of immunostaining appears to parallel the pattern of glycine labeling seen previously with autoradiographic techniques and implicates these cells in glycine-mediated neurotransmission.
\end{abstract}

It is widely accepted that glycine (GLY) serves as an inhibitory neurotransmitter in the vertebrate retina (see review, Marc, 1985). Evidence supporting this view includes the presence of a high-affinity uptake system (Bruun and Ehinger, 1972; Chin and Lam, 1980), light-stimulated release (Ehinger and Lindberg, 1974; Ehinger and Lindberg-Bauer, 1976), and powerful effects of GLY and the GLY antagonist strychnine on ganglion cells (Kirby, 1979; Frumkes et al., 1981; Miller et al., 1981; Ikeda and Sheardown, 1983; Bolz et al., 1985). Efforts to provide a morphological identification of putative glycinergic neurons have. consistently implicated subpopulations of amacrine cells (Ehinger and Falck, 1971; Bruun and Ehinger, 1974; Marshall and Voaden, 1974; Voaden, 1976; Nakamura et al., 1978; Pourcho, 1980; Frederick et al., 1984; Marc and Liu, 1985; Pourcho and Goebel, 1985a). In addition, interplexiform cells in the goldfish (Marc and Lam, 1981) and cone bipolar cells in several species (McGuire et al., 1980; Pourcho, 1980; Pourcho et al., 1984; Cohen and Sterling, 1985; Pourcho and Goebel, 1986, 1987) have been shown to label with ${ }^{3} \mathrm{H}-\mathrm{GLY}$.

More specific identifications of putative glycinergic neurons have been made in the cat retina. Studies in our laboratory using a combination of Golgi impregnation and electron-microscopic autoradiography have shown 4 types of amacrine cells that label with ${ }^{3} \mathrm{H}-$ GLY (Pourcho and Gocbcl, 1985a). These cells cor-

Received Aug. 13, 1986; revised Oct. 16, 1986; accepted Oct. 17, 1986.

This work was supported by NIH Research Grant EY02267 and Core Vision Grant EY04068 from the National Eye Institute.

Correspondence should be addressed to Roberta G. Pourcho, Department of Anatomy and Cell Biology, School of Medicine, Wayne State University, $540 \mathrm{E}$. Canfield, Detroit, MI 48201.

Copyright $\mathfrak{A} 1987$ Society for Neuroscience $0270-6474 / 87 / 041189-09 \$ 02.00 / 0$ respond to amacrine cell types $\mathrm{A} 3, \mathrm{~A} 4, \mathrm{~A} 7(\mathrm{AII})$, and $\mathrm{A} 8$ as describcd by Kolb ct al. (1981). Of these, the A 8 was the most heavily labeled cell type, while A4 amacrines were moderately labeled and A3 and A4 cells were lightly labeled. In addition, cone bipolar types $\mathrm{CBb} 2$ and $\mathrm{CBb} 5$ were found to be moderately labeled with ${ }^{3} \mathrm{H}-\mathrm{GLY}$, while types $\mathrm{CBa} 2, \mathrm{CBa} 6, \mathrm{CBb} 1$, and $\mathrm{CBb} 3$ were lightly labeled (Pourcho and Goebel, 1986, 1987). Cohen and Sterling (1985) have also reported accumulation of ${ }^{3} \mathrm{H}-\mathrm{GLY}$ by several types of cone bipolar cells in the cat retina, specifically those cells that ramify in sublamina $b$.

The identification of specific glycinergic cells has depended heavily upon autoradiographic techniques since there is no specific synthesizing enzyme for GLY which lends itself to immunocytochemical localization. However, a major concern in these studies, as in all autoradiographic studies, is whether the ability of a given cell type to accumulate a putative amino acid transmitter is an accurate reflection of its endogenous content of that transmitter. This concern is particularly pronounced in the case of GLY, which is known to be incorporated into numerous peptides and proteins. Recently, methods have been developed permitting the direct immunocytochemical visualization of amino acids (Storm-Mathisen et al., 1983; Seguela et al., 1984). These methods have been applied to the localization of a number of amino acids, including GABA (Storm-Mathisen et al., 1983), glutamate (Ottersen and Storm-Mathisen, 1984), GLY (Pourcho and Goebel, 1985b), and taurine (Campistron et al., 1986).

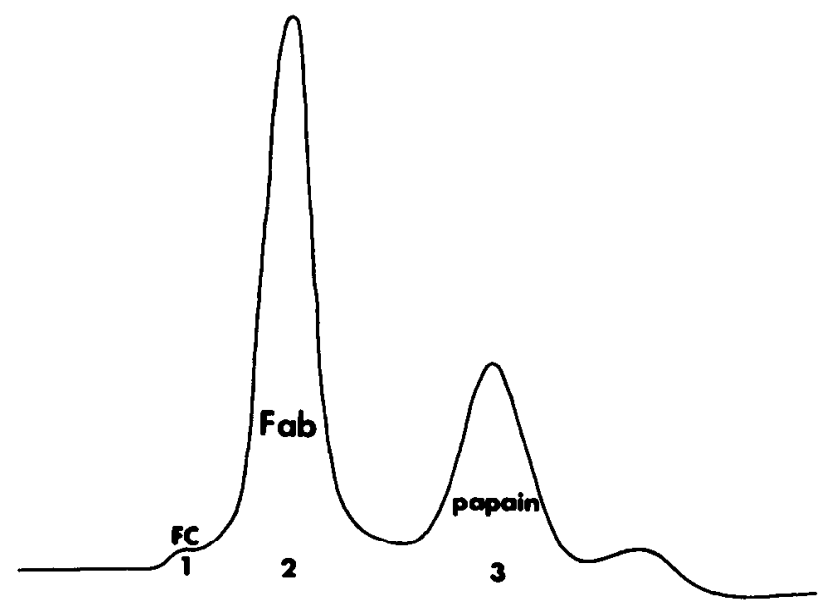

Figure 1. Chromatograph of papain hydrolysate of GLY antiserum on a column of Sephadex G-100. The first peak contains Fc fragments that had not been precipitated. The large second peak exhibited immunoreactivity to GLY-G, while the third peak was found to co-elute with papain. 

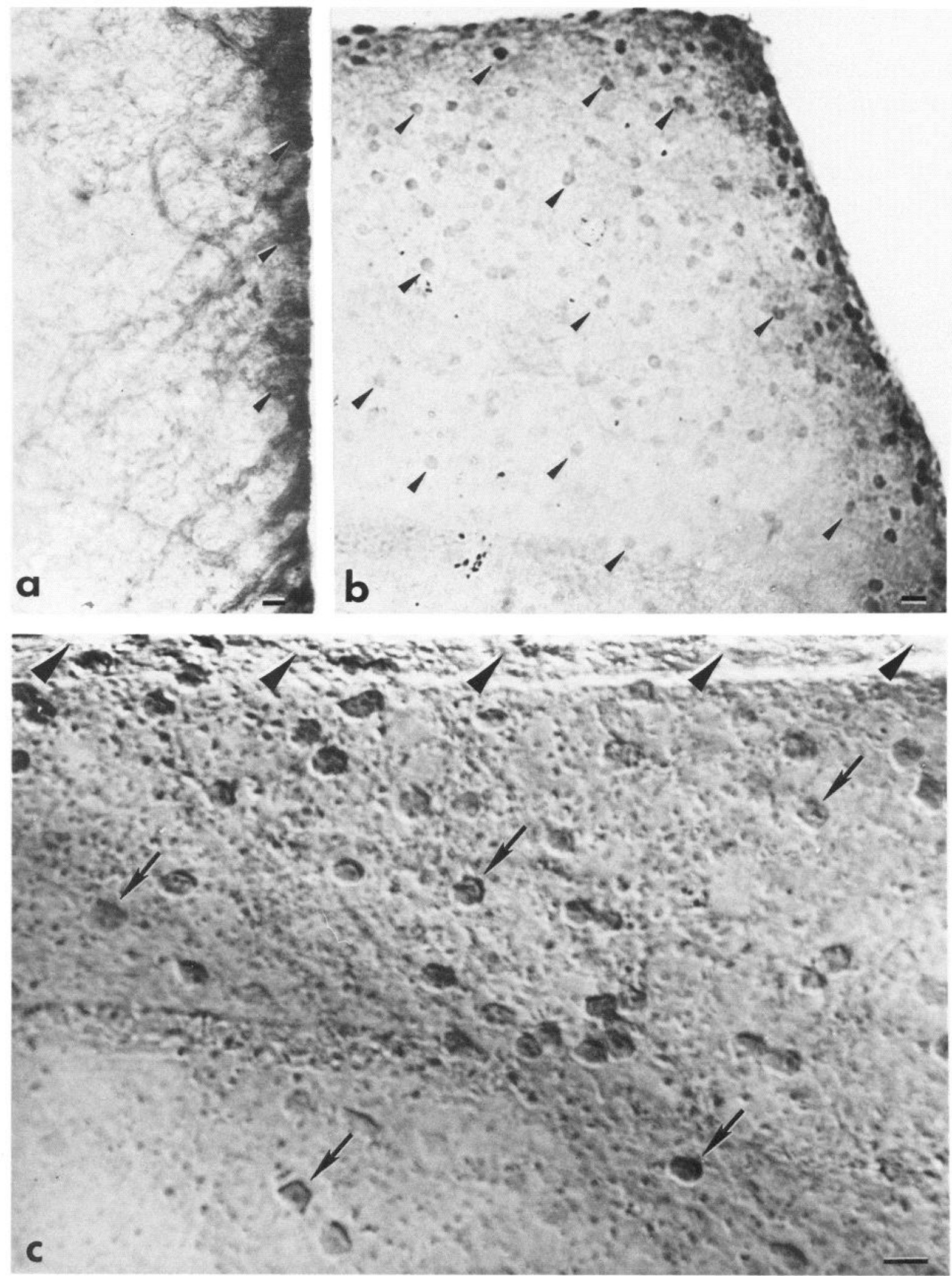

Figure 2. Flat-mount preparations of cat retina fixed in $4 \%$ paraformaldehyde and $0.1 \%$ glutaraldehyde and then reacted for GLY immunoreactivity. $a$, Tissue reacted with whole antiserum, goat antirabbit IgG, and rabbit PAP shows only limited penetration of immunoreagents. A few reactive cell bodies (arrowheads) near the edge of the tissue can be distinguished. $b$, Tissue reacted with Fab fragments of GLY antiserum and Fab-specific secondary and tertiary sera. Immunostaining of cell bodies (arrowheads) can be seen up to $150 \mu \mathrm{m}$ from the cut surface. $c$, Higher magnification of tissue in $b$ photographed using Nomarski optics. Cell bodies (arrows) are clearly visible. Arrowheads designate the cut edge of the tissue. Scale bars, $10 \mu \mathrm{m}$. 


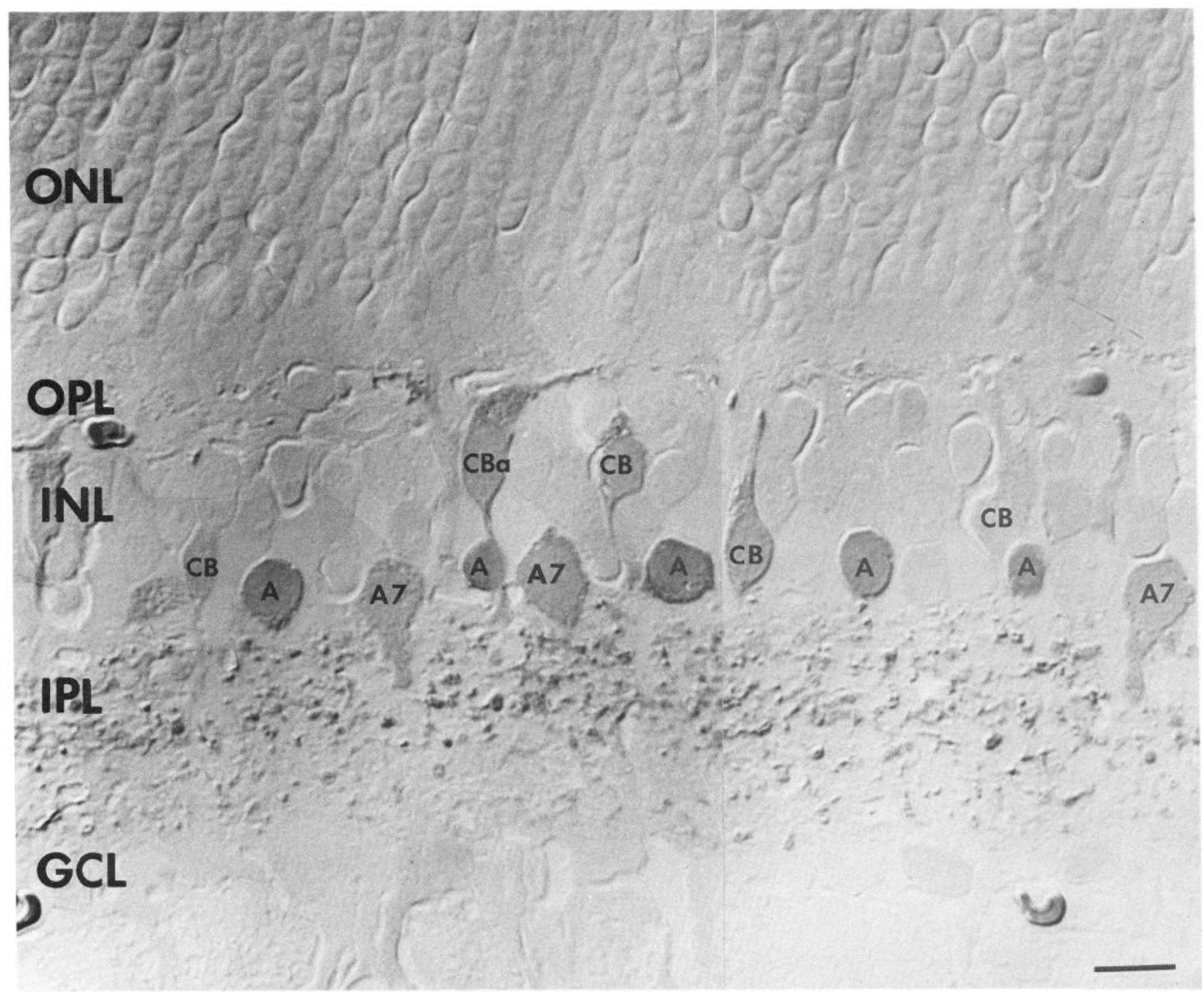

Figure 3. One micron section of cat retina, reacted with Fab immunoreagents and photographed with Nomarski optics. A number of morphologically distinct subpopulations within the inner nuclear layer $(I N L)$ are seen to be immunoreactive. The amacrine layer cells include moderately stained A7(AII) cells. Other more reactive amacrine cells $(A)$ are also seen. Some of the cone bipolar $(C B)$ cells exhibit GLY immunoreactivity. Staining was more intense in the outer portion of the inner plexiform layer $(I P L)$ than in the inner portion. No staining was seen in the outer nuclear layer $(O N L) . O P L$, outer plexiform layer; $G C L$, ganglion cell layer. Scale bar, $10 \mu \mathrm{m}$.

The antigen used in each of these immunocytochemical studies is the appropriate amino acid conjuated by the use of glutaraldehyde to a carrier molecule such as serum albumin or thyroglobulin. Thus, the antibody is not generated against the native amino acid but against an aldehyde-modified amino acid. Visualization of the amino acid in tissue requires an initial fixation with glutaraldehyde to modify in situ amino acids to match the conformation of the antigen. The dependence of the method upon glutaraldehyde fixation is illustrated by the failure of preabsorption with native amino acids to block immunoreactivity, whereas preabsorption with glutaraldehyde-modified amino acids abolishes the immunoreactivity (Pourcho and Goebel, 1985b). However, the use of glutaraldehyde increases crosslinking of proteins and compounds the problem of tissue penetration not only for the primary antiserum, but also for additional immunoreagents.

The issue of immunoreagent penetration was addressed in a recent study by Brandon (1985), in which he reported that the use of Fab fragments of a primary antibody in conjunction with Fab specific secondary and tertiary reagents results in a 5- to 10 -fold increase in the depth of immunostaining. Since Brandon's study was directed at the localization of an antiserum against glutamate decarboxylase (GAD), the tissue was fixed in paraformaldehyde alone. We reasoned that if the use of Fab fragments could make such a significant improvement in tissue penetration for GAD visualization, application of similar techniques should prove valuable for the immunocytochemical study of amino acids in glutaraldehyde-fixed tissue, where penetration is even more limited.

In the present study, we have adapted Fab techniques to the localization of GLY antiserum in the cat retina. We were particularly interested in determining whether the cell types that had been found by autoradiographic studies to exhibit highaffinity uptake of glycine also contain high levels of endogenous 


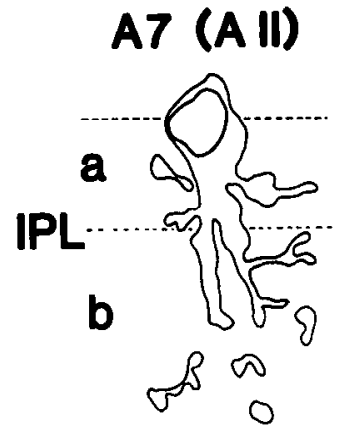

(a)
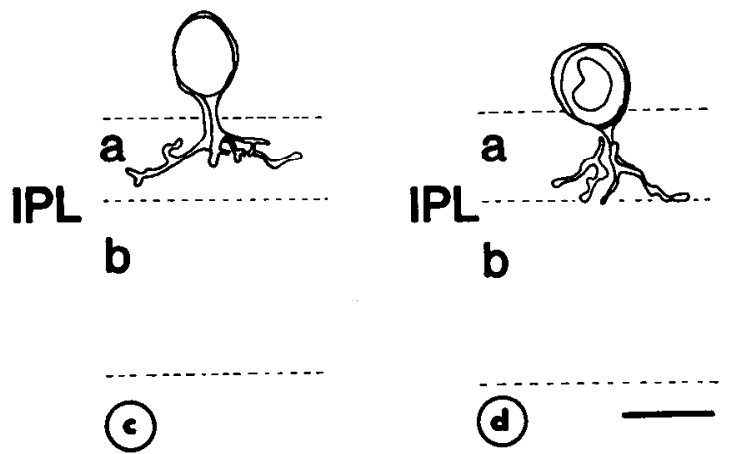

Figure 4. Reconstruction of GLY immunoreactive amacrine cells from serial $1 \mu \mathrm{m}$ sections. $a$, Characteristic A7(AII) amacrine exhibits a thick descending dendrite that bifurcates near the $a / b$ sublaminar border. $b$, Strongly immunoreactive amacrine cell with a thin dendrite extending into sublamina $b . c$ and $d$, Additional immunoreactive amacrine cells, both ramifying in sublamina $a$. Scale bar, $10 \mu \mathrm{m}$.

GLY. The improved tissue penetration achieved through the use of Fab fragments made it possible to identify a number of specific cells. The distribution of GLY-like immunoreactivity appears to parallel the pattern seen previously with high-affinity uptake and confirms the presence of large stores of endogenous GLY in both amacrine and cone bipolar populations.

\section{Materials and Methods}

Primary antiserum. The primary antiserum used in this study was generated against GLY conjugated by glutaraldehyde $(G)$ to BSA, following the method introduced by Storm-Mathisen ct al. (1983). The details of preparation have been described previously (Pourcho and Goebel, 1985b). The whole antiserum was passed through an affinity column of BSAG-GLY and eluted with $3 \mathrm{M} \mathrm{KSCN}$. After further purification against BSA-G and BSA-G-GABA columns, the serum was found to be highly selective for GLY-G, as evidenced by spot tests of reagents applied to nitrocellulose paper (Pourcho and Goebel, 1985b). Aliquots of the purified antiserum were lyophilized and stored at $-70^{\circ} \mathrm{C}$ until being used for preparation of Fab fragments.

Preparation of Fab fragments. The procedure for preparation of Fab fragments was adapted from Brandon (1985). For hydrolysis, 2 units mercuripapain (Sigma), $3 \mathrm{~mm}$ EDTA, and $35 \mathrm{~mm}$ mercaptoethanol were added to a sample containing $\mathrm{IgG}$ from $1 \mathrm{ml}$ whole serum. The mixture was then incubated for $5 \mathrm{~d}$ at $4^{\circ} \mathrm{C}$. The hydrolysate was dialyzed in benzoylated tubing against several changes of PBS over $48 \mathrm{hr}$ and then centrifuged at $10,000 \times g$ for 10 min to precipitate $F c$ fragments. The supernatant was concentrated using an Amicon stir cell with YM5 membrane and applied to a Sephadex G-100 column $(1.5 \times 30 \mathrm{~cm})$. Fractions were eluted with PBS, pH 7.4, at a flow rate of $10 \mathrm{ml} / \mathrm{hr}$ and monitored at $280 \mathrm{~nm}$ absorbance. After testing for immunoreactivity, appropriate fractions were concentrated to original serum volume, lyophilized, and stored in a dessicator at $-70^{\circ} \mathrm{C}$.
Table 1. Percentages of GLY-containing cells in cat retina

\begin{tabular}{|c|c|c|c|}
\hline \multirow[b]{2}{*}{ Cell layer } & \multicolumn{2}{|c|}{${ }^{3} \mathrm{H}-\mathrm{GLY}$ uptake (\%) } & \multirow{2}{*}{$\begin{array}{l}\text { GLY } \\
\text { immuno- } \\
\text { reactivity } \\
(\%) \\
\end{array}$} \\
\hline & $\begin{array}{l}\text { Pourcho } \\
(1980)\end{array}$ & $\begin{array}{l}\text { Wässle et al. } \\
(1986)\end{array}$ & \\
\hline Amacrine & 43 & 46 & 50 \\
\hline Bipolar & NA & 11.5 & 14.7 \\
\hline Ganglion cell & $\mathrm{NA}$ & $\begin{array}{l}\text { Mostly } \mathrm{dA} \text { and } \\
\text { astrocytes }\end{array}$ & 13 \\
\hline
\end{tabular}

Immunocytochemistry. Freshly dissected cat retinas were fixed overnight in $4 \%$ paraformaldehyde with $0.1 \% \mathrm{G}$ in $0.1 \mathrm{~m}$ phosphate buffer. The tissue was then washed with buffer and immersed in 30\% sucrose at $4^{\circ} \mathrm{C}$ overnight. The retinas were cut into $2 \mathrm{~mm}$ pieces with a razor blade and, while still in $30 \%$ sucrose, were frozen in liquid nitrogen and allowed to thaw at room temperature.

Remaining aldehydes were quenched by incubation in $1 \mathrm{~m}$ ethanolamine in phosphate buffer, $\mathrm{pH} 7.2$, for $1 \mathrm{hr}$. Samples were then washed in $0.1 \mathrm{~m}$ Tris saline (TS), $\mathrm{pH} 7.4$, and preincubated with $1 \%$ BSA in TS for $1 \mathrm{hr}$ at room temperature. The TS with $1 \%$ BSA was also used as the diluant for all antisera. Tissue was incubated for $2-4 \mathrm{~d}$ at $4{ }^{\circ} \mathrm{C}$ with Fab fragments of glycine antiserum at a dilution of 1:100 based on whole serum. After several TS washes, retinal slices were placed in 1:50 goat antirabbit $\mathrm{IgG} \mathrm{F}\left(\mathrm{ab}^{\prime}\right)_{2}$-specific serum (Cappel Worthington) and incubated overnight in the cold. Following another series of TS washes, tissue was immersed in 1:100 rabbit Fab PAP (Jackson ImmunoResearch, Avondale, PA) and incubated overnight in the cold. Tissue was then washed again in TS, reacted for $10 \mathrm{~min}$ with $5 \mathrm{mg} / \mathrm{ml}$ diaminobenzidine (DAB) without $\mathrm{H}_{2} \mathrm{O}_{2}$ followed by 4 min in DAB containing $0.01 \% \mathrm{H}_{2} \mathrm{O}_{2}$. After successive washes in TS and $0.1 \mathrm{M}$ phosphate buffer, the tissue was postfixed in $3 \% \mathrm{G}$ followed by a second postfixation in $2 \%$ osmium tetroxide. Samples were dehydrated through graded alcohols and propylene oxide, then embedded in Epon-Araldite.

The retinas were viewed in flat-mount preparations or sectioned for light and electron microscopy. One micron sections were examined without additional staining and photographed using Nomarski optics. Cell counts from these sections were made to determine the percentages of immunoreactive cells in the various layers of the retina. Thin sections for electron microscopy were stained with uranyl acetate and lead citrate before viewing. Both light-microscopic sections and electron micrographs were used for preparation of reconstructions of immunoreactive neurons.

\section{Results}

The papain hydrolysate of GLY antiserum contained several components that were separated on a Sephadex G-100 column (Fig. 1). These included a small initial peak of unprecipitated Fc fragments, a large second peak that exhibited strong immunoreactivity to GLY-G, and a third peak that co-eluted with papain. The fractions containing the Fab peak were combined for use in immunocytochemistry.

Cat retinas reacted with Fab fragments of the GLY antiserum and processed with Fab-specific secondary and tertiary antisera showed an increased penetration of immunoreagents compared with retinas treated with whole antisera (Fig. 2). In retinas incubated with unfragmented GLY antiserum, immunoreactive cell bodies were seen only within $10-15 \mu \mathrm{m}$ of cut surfaces, while in retinas reacted with the smaller Fab fragments, staining of cell bodies was clearly evident at distances up to $150 \mu \mathrm{m}$ from exposed surfaces. A gradual diminution in staining intensity further into the tissue indicated that immunoreagent penetration occurred primarily from the edges of retinal pieces rather than through the inner or outer limiting membrane. In view of this observation, care was taken during the preparation of radial sections to assure that specimens were oriented parallel 


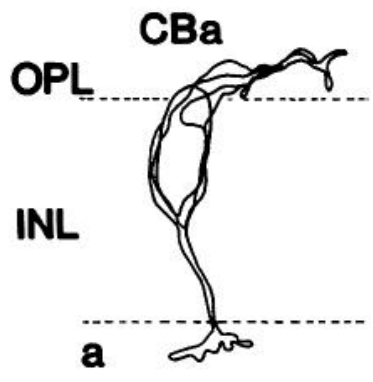

IPL

b

()

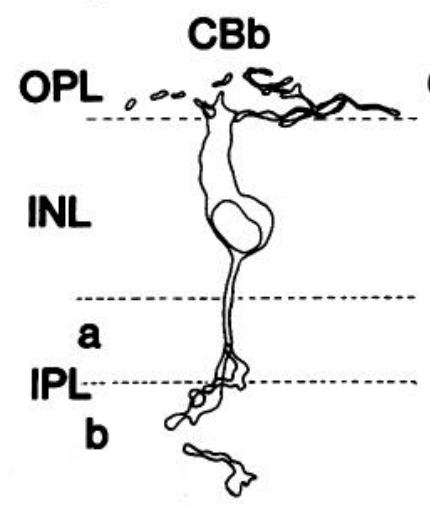

()

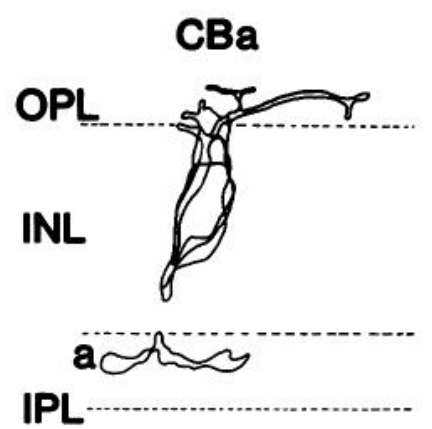

b
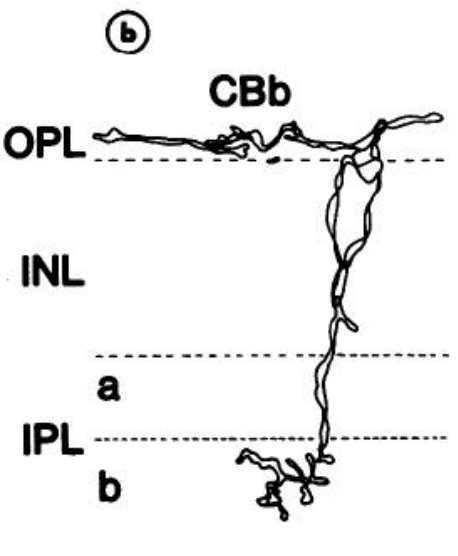

(a)

Figure 5. Reconstruction of GLY immunoreactive cone bipolar cells from serial $1 \mu \mathrm{m}$ sections. $a$ and $b$, Type CBa cone bipolar cells with axons terminating in sublamina $a . c$ and $d$, Type CBb cone bipolar cells with axons terminating in sublamina $b$. Scale bar, $10 \mu \mathrm{m}$.

to cut edges so that all of the cells in a given section would have received equal exposure to the immunoreagents.

The intensity of immunoreactivity as seen in radial sections varied widely among the subpopulations of retinal neurons (Fig. 3). The most heavily reactive cells were seen in the amacrine portion of the inner nuclear layer (INL). More lightly stained amacrines could also be seen. Among these were cells exhibiting the distinctive oval soma and thick descending dendrite of AII or A7 amacrines (Famiglietti and Kolb, 1975; Kolb et al., 1981). In addition, several types of cone bipolar cells, identified by their ascending dendrites, were seen to be immunoreactive (Fig. 3). Other subpopulations of amacrine and bipolar cells appeared nonreactive. Horizontal cells and photoreceptor cells were consistently free of GLY immunoreactivity. Large ganglion cells were also nonreactive, although some small neurons in the ganglion cell layer appeared to be stained. These are likely to be displaced amacrines and glial cells (Wässle et al., 1986). Within the inner plexiform layer, staining was concentrated in the outer strata $(s 1,2,3)$ while some reactive processes could be seen ramifying in $\mathrm{s} 4$ and $\mathrm{s} 5$.

Cell counts showed that approximately $50 \%$ of the cells in the amacrine portion of the INL exhibited GLY immunoreactivity, while $15 \%$ of the cells in the bipolar layers were stained

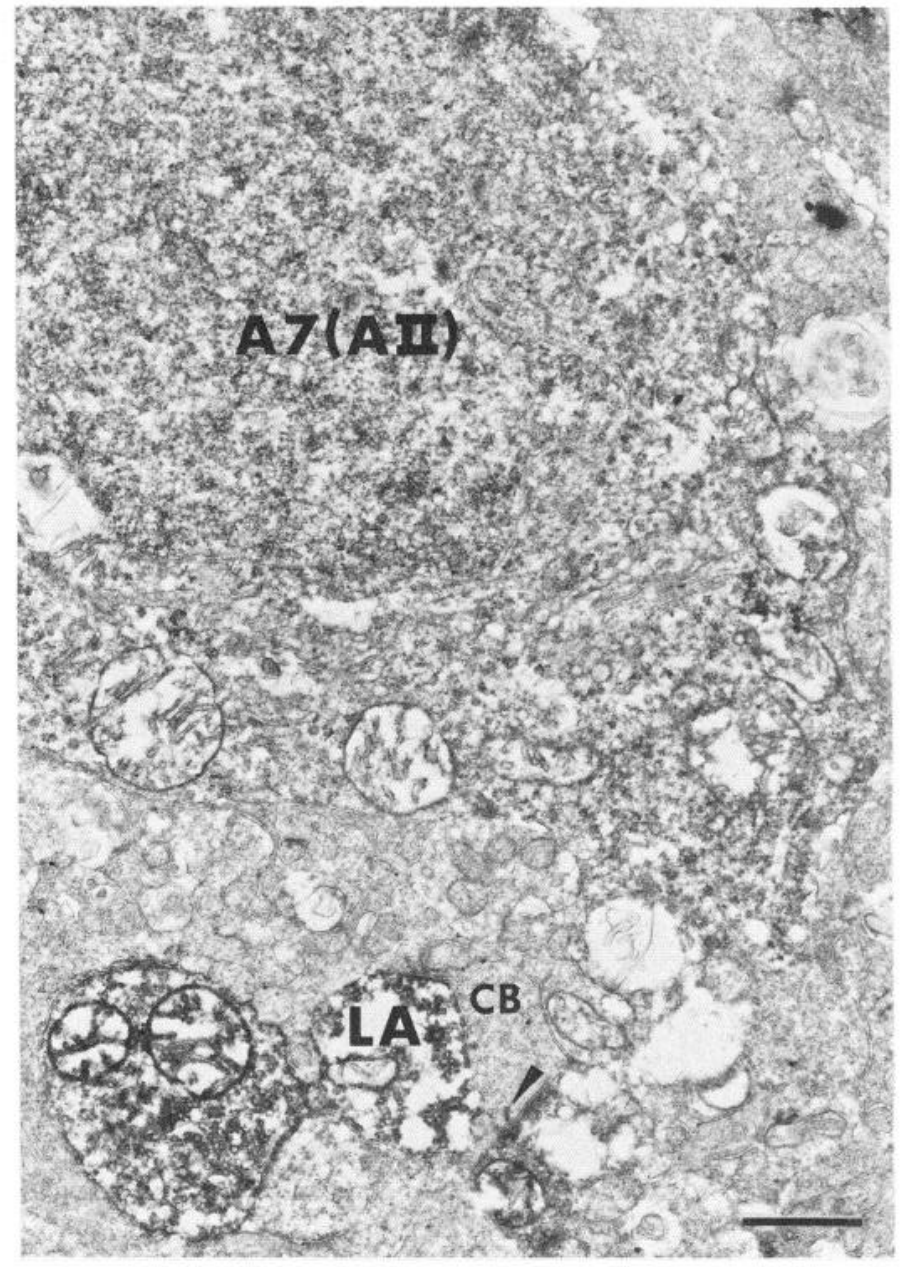

Figure 6. Electron micrograph of GLY immunoreactive A7(AII) amacrine cell. Reaction product is present in both cytoplasm and nucleus of this cell. The lobular appendage $(L A)$, which is strongly immunoreactive, can be seen to receive synaptic input from a cone bipolar $(C B)$ cell whose ribbon is indicated (arrow). Scale bar, $1 \mu \mathrm{m}$.

(Table 1). It must be noted that a number of the cells in the amacrine layer are actually cone bipolar cells (Fig. 3), while some amacrines may also be present in the upper layers of the INL. Despite these considerations, there is a good correspondence between the percentages of cells exhibiting GLY immunoreactivity with the percentages of cells found to be labeled with ${ }^{3} \mathrm{H}-\mathrm{GLY}$ (Pourcho, 1980; Wässle et al., 1986).

Reconstructions of reactive cells from serial $1 \mu \mathrm{m}$ sections confirmed the identification of A7(AII) amacrines (Fig. 4a). In addition, several other cell types were found. The cell illustrated in Figure $4 b$ was the most strongly immunoreactive of all of the neurons. Although this cell cannot be clearly identified, it may be a type A8 amacrine since these cells were shown to accumulate ${ }^{3} \mathrm{H}-\mathrm{GLY}$ more avidly than the other amacrine cells (Pourcho and Goebel, 1985a). The other 2 amacrines illustrated (Fig. 4, $c, d$ ) were lightly to moderately immunoreactive and appeared to ramify entirely within sublamina $a$. Comparison with earlier autoradiographic data (Pourcho and Goebel, 1985a) suggests that these cells may be A3 and A4 amacrines. Several types of GLY-immunoreactive cone bipolar cells were also seen (Fig. 5). These included cells with axons terminating in sublamina $a$ (Fig. $5, a, b$ ), as well as cells with axons ramifying in sublamina $b$ (Fig. $5, c, d$ ). 


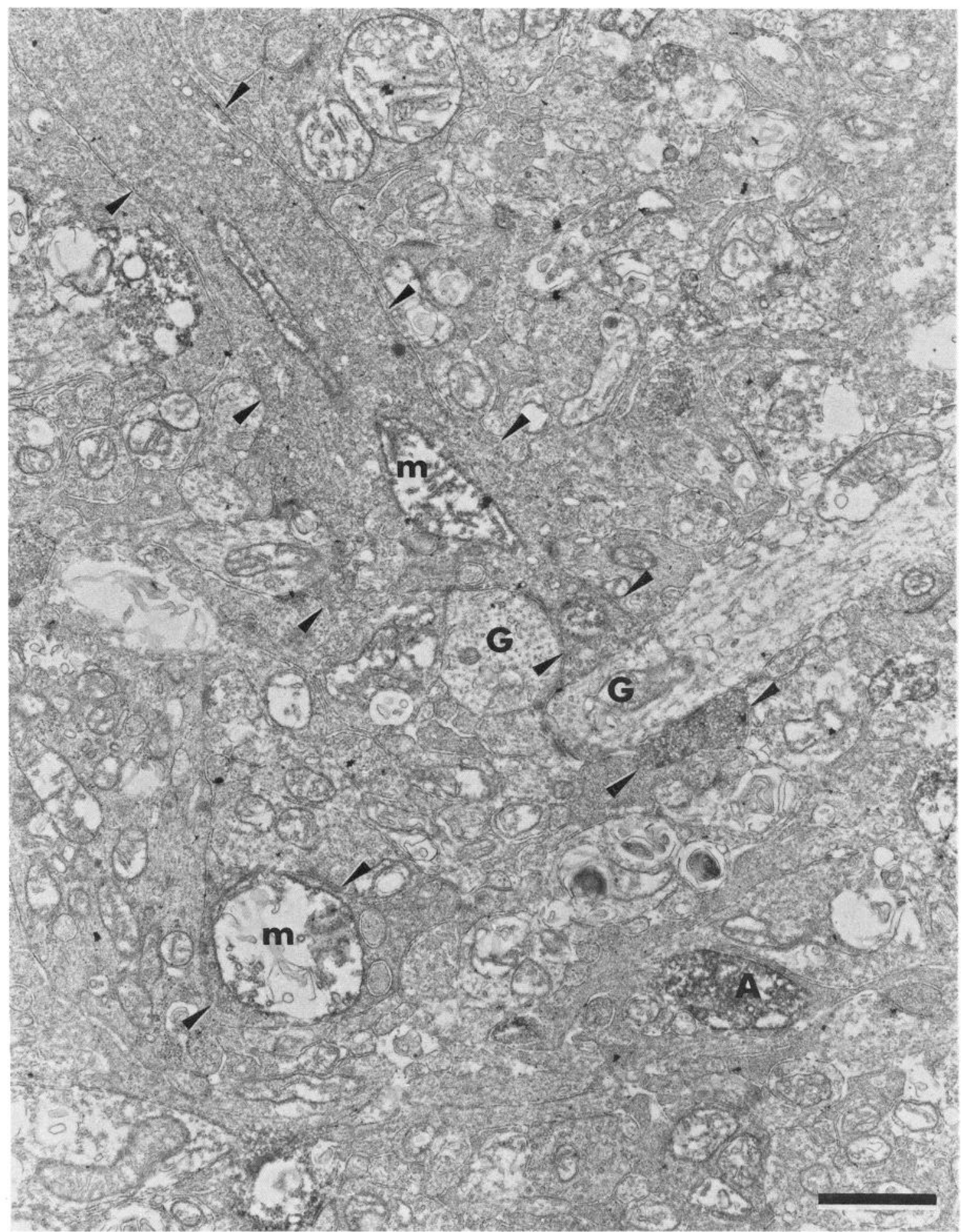

Figure 7. Electron micrograph showing the axon of a GLY immunoreactive cone bipolar cell (arrowheads) that extends into sublamina $b$. Note the increased staining of the axon as it nears the terminal region, where it makes contact with a ganglion cell $(G)$. Mitochondria $(m)$ appear stained as well. Several other immunoreactive processes are seen within the field, among them a strongly immunoreactive amacrine $(A)$ cell process. Scale bar, $1 \mu \mathrm{m}$.

Electron micrographs showed GLY immunostaining to be distributed through both cytoplasm and nucleoplasm of reactive cells, as illustrated in Figure 6 . This cell was identified as an A7(AII) amacrine because of its oval soma, large mitochondria, and characteristic lobular appendages (Famiglietti and Kolb,
1975; Kolb et al., 1981). However, the distribution of GLY immunoreactivity throughout a given cell was not always uniform. The cone bipolar cell seen in Figure 7 showed very little reaction product in much of its descending axon but appeared more strongly immunoreactive near the axon terminal. The 


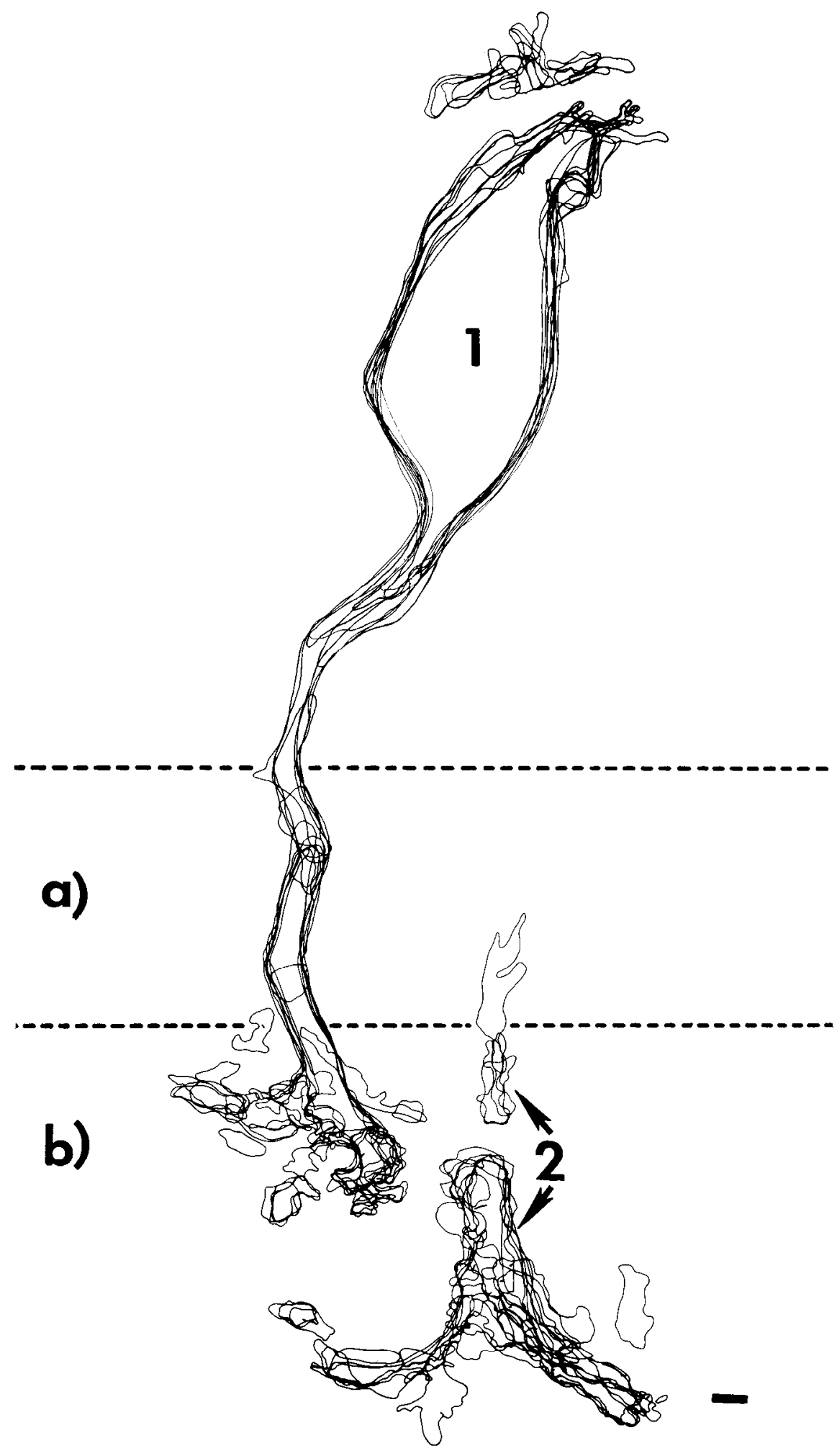

Figure 8. Reconstruction of 2 cone bipolar cells that exhibited GLY immunostaining. Both cells send their axons through sublamina $a$ to terminate in sublamina $b$. Cell 1 was tentatively identified as a $\mathrm{CBb} 1$ cone bipolar, while cell 2 appears to be a CBb2 cell. Scale bar, $1 \mu \mathrm{m}$. 
soma of this cell (not illustrated) was also stained. A reconstruction made from a short series of electron micrographs shows a pair of immunoreactive cone bipolar cells (Fig. 8). The axon of cell 1 exhibits the vertical orientation characteristic of $\mathrm{CBb} 1$ cells (McGuire et al., 1984; Pourcho and Goebel, 1987), while cell 2 , which ramified somewhat deeper in sublamina $b$, was tentatively identified as a $\mathrm{CBb} 2$. Both of these cell types have been reported previously to accumulate ${ }^{3} \mathrm{H}-\mathrm{GLY}$ (Cohen and Sterling, 1985; Pourcho and Goebel, 1986, 1987).

\section{Discussion}

The use of Fab fragments of GLY antiserum in conjunction with Fab-specific secondary and tertiary antisera has improved the penetration of immunoreagents into cat retina and facilitated the identification of a number of reactive cells. Fab-specific immunoreagents also increased the specificity of the immunostaining as compared with the results obtained with whole serum (Pourcho and Goebel, 1985b). The secondary and tertiary reagents used to visualize whole serum produced a nonspecific staining of photoreceptor cells and fiber layer that was eliminated in Fab-reacted tissue (Fig. 3)

An immediate concern in the use of an antiserum generated against an amino acid such as GLY is that endogenous levels in all cells might be so high that useful distinctions would be impossible. The present study shows that individual cells exhibit marked variations in levels of immunoreactivity, ranging from no visible staining to strong reactivity. Thus, it appears that the amount of GLY present in all cells as part of a general metabolic pool is below the limits of detection with the present methodology. The more positive corollary of this observation is that the cells exhibiting visible levels of immunoreactivity contain particularly high levels of GLY for a specific function - such as utilization of the amino acid as a neurotransmitter. It must be recognized that this immunoreactivity is best described as GLYlike immunoreactivity. However, to the extent that this antiserum accurately reflects GLY localizations, the results indicate wide variations in the endogenous GLY content of retinal neurons.

The distribution of GLY immunoreactivity in specific subpopulations of cat retinal neurons appears to parallel the localization of ${ }^{3} \mathrm{H}-\mathrm{GLY}$ seen in autoradiographic studies (Pourcho, 1980; Pourcho and Goebel, 1985a, 1986, 1987). Furthermore, the levels of immunostaining in individual neurons appeared consistent with the results of quantitative autoradiography of ${ }^{3} \mathrm{H}-\mathrm{GLY}$ accumulation by these same cell types. In the present study, the distinctive A7 or AII (Famiglietti and Kolb, 1975) rod amacrines were found to contain low to moderate levels of GLY-like immunoreactivity (Figs. 3, 4a, 6). Other cells, more heavily labeled, are likely to be A8 amacrines (Figs. 3, 4b). Possible candidates for A3 and A4 amacrines were also seen to be immunoreactive (Fig. $4, c, d$ ). Evidence obtained to date with regard to specific identification of GLY immunoreactive cone bipolar cells also shows a high level of correspondence with cells identified from combined Golgi and autoradiographic studies (Pourcho and Goebel, 1986, 1987). Both ${ }^{3} \mathrm{H}-\mathrm{GLY}$ labeling and GLY-like immunoreactivity were seen in a number of cone bipolar populations, including cells with axonal ramifications in sublaminas $a$ and $b$ (Fig. 5). Types CBb1 and CBb2 could be identified among the sublamina $b$ cells (Figs. 7, 8).

Although it is generally agreed that GLY functions as a neurotransmitter for a number of amacrine subpopulations, there is not widespread agreement regarding the possibility of GLY as a transmitter for bipolar cells. Since bipolars provide the direct input to ganglion cells, it has frequently been assumed that they should be excitatory. However, Sterling and coworkers (Sterling, 1983; McGuire et al., 1984, 1986) have proposed a push-pull hypothesis in which specific ganglion cells receive input from both excitatory and inhibitory bipolar cells. More recently, Wässle et al. (1986) have tested this hypothesis through the use of aminophosphonobutyric acid, which blocks the responses of On-center bipolar cells without affecting the response of Off-center bipolars (Slaughter and Miller, 1981). Their results were consistent with the possibility that On-bipolar cells provide inhibitory input to Off-center ganglion cells. By demonstrating that several populations of cone bipolar cells contain significant stores of endogenous GLY, the present study also supports this possibility.

In summary, the present study has demonstrated that use of Fab fragments improves the penetration of GLY antiserum into cat retina, facilitating the identification of specific neurons that contain high levels of endogenous GLY. This methodology provides a useful adjunct to autoradiographic techniques for the elucidation of neurochemical circuitry. The findings implicate multiple subpopulations of both amacrine and cone bipolar cells in GLY-mediated transmission in the cat retina.

\section{References}

Bolz, J., T. E. Frumkes, T. Voight, and H. Wässle (1985) Action and localization of glycine and taurine in the cat retina. J. Physiol. (Lond.) 362: 369-393.

Brandon, C. (1985) Improved immunocytochemical staining through the use of Fab fragments of primary antibody, Fab-specific second antibody, and Fab-horseradish peroxidase. J. Histochem. Cytochem. 33: 715-719.

Bruun, A., and B. Ehinger (1972) Uptake of the putative neurotransmitter, glycine, into the rabbit retina. Invest. Ophthalmol. 11: 191198.

Bruun, A., and B. Ehinger (1974) Uptake of certain possible neurotransmitters into retinal neurones of some mammals. Exp. Eye Res. 19: 435-447.

Campistron, G., M. Geffard, and R. M. Buijs (1986) Immunological approach to taurine and immunocytochemical results. J. Neurochem. 46: 862-868.

Chin, C.-A., and D. M.-K. Lam (1980) The uptake and release of $\left.{ }^{(}{ }^{3} \mathrm{H}\right)$ glycine in the goldfish retina. J. Physiol. (Lond.) 308: 185-195.

Cohen, E., and P. Sterling (1985) Glycine accumulation by cone bipolar neurons in the cat retina. Invest. Ophthalmol. Vis. Sci. Suppl. 26: 95 .

Ehinger, B., and B. Falck (1971) Autoradiography of some suspected neurotransmitter substances: GABA, glycine, glutamic acid, histamine, dopamine, and L-dopa. Brain Res. 33: 157-172.

Ehinger, B., and B. Lindberg (1974) Light-evoked release of glycine from the retina. Nature 251: 717-728.

Ehinger, B., and B. Lindberg-Bauer (1976) Light-evoked release of glycine from cat and rabbit retina. Brain Res. 113: 535-549.

Famiglietti, E. V., Jr., and H. Kolb (1975) A bistratified amacrine cell and synaptic circuitry in the inner plexiform layer of the retina. Brain Res. 84: 293-300.

Frederick, J. M., M. E. Rayborn, and J. G. Hollyfield (1984) Glycinergic neurons in the human retina. J. Comp. Neurol. 227: 159-172.

Frumkes, T. E., R. F. Miller, M. Slaughter, and R. F. Dacheux (1981) Physiological and pharmacological basis of GABA and glycine action on neurons of mudpuppy retina. III. Amacrine-mediated inhibitory influences on ganglion cell receptive-field organization: A model. J. Neurophysiol. 45: 783-804.

Ikeda, H., and M. Sheardown (1983) Functional transmitters at retinal ganglion cells in the cat. Vision Res. 23: 1161-1174.

Kirby, A. W. (1979) The effect of strychnine, bicuculline, and picrotoxin on $\mathrm{X}$ and $\mathrm{Y}$ cells in the cat retina. J. Gen. Physiol. 74: 71-84. 
Kolb, H., R. Nelson, and A. Mariani (1981) Amacrine cells, bipolar cells and ganglion cells of the cat retina: A Golgi study. Vision Res. 21: $1081-1114$.

Marc, R. E. (1985) The role of glycine in retinal circuitry. In Retinal Transmitters and Modulators: Models for the Brain, W. W. Morgan, ed., Vol. 1, pp. 119-158, CRC Press, Boca Raton, FL.

Marc, R. E., and D. M.-K. Lam (1981) Glycinergic pathways in the goldfish retina. J. Neurosci. 1: 152-165.

Marc, R. E., and W.-L. S. Liu (1985) $\left({ }^{3} \mathrm{H}\right)$ Glycine-accumulating neurons of the human retina. J. Comp. Neurol. 232: 241-260.

Marshall, J., and M. J. Voaden (1974) An investigation of the cells incorporating $\left({ }^{3} \mathrm{H}\right)$ GABA and $\left({ }^{3} \mathrm{H}\right)$ glycine in the isolated retina of the rat. Exp. Eye Res. 18: 367-370.

McGuire, B. A., J. K. Stevens, and P. Sterling (1980) Beta ganglion cells receive convergent input from two types of cone bipolar cells. Soc. Neurosci. Abstr. 6: 347.

McGuire, B. A., J. K. Stevens, and P. Sterling (1984) Microcircuitry of bipolar cells in cat retina. J. Neurosci. 4: 2920-2938.

McGuire, B. A., J. K. Stevens, and P. Sterling (1986) Microcircuitry of beta ganglion cells in cat retina. J. Neurosci. 6: 907-918.

Miller, R. F., T. E. Frumkes, M. Slaughter, and R. F. Dacheux (1981) Physiological and pharmacological basis of GABA and glycine action on neurons of mudpuppy retina. II. Amacrine and ganglion cells. J. Neurophysiol. 45: 764-782.

Nakamura, Y., B. McGuire, and P. Sterling (1978) Selective uptake of $\gamma-\left({ }^{3} \mathrm{II}\right)$-aminobutyric acid and $\left({ }^{3} \mathrm{H}\right)$ glycine by neurons of the amacrine layer of cat retina. Soc. Neurosci. Abstr. 4: 2046.

Ottersen, O. P., and J. Storm-Mathisen (1984) Glutamate- and GABAcontaining neurons in the mouse and rat brain, as demonstrated with a new immunocytochemical technique. J. Comp. Neurol. 229: 374 392.
Pourcho, R. G. (1980) Uptake of $\left({ }^{3} \mathrm{H}\right)$ glycine and $\left({ }^{3} \mathrm{H}\right) \mathrm{GABA}$ by amacrine cells in the cat retina. Brain Res. 198: 333-346.

Pourcho, R. G., and D. J. Goebel (1985a) A combined Golgi and autoradiographic study of $\left({ }^{3} \mathrm{H}\right)$ glycine-accumulating amacrine cells in the cat retina. J. Comp. Neurol. 233: 473-480.

Pourcho, R. G., and D. J. Goebel (1985b) Immunocytochemical demonstration of glycine in retina. Brain Res. 348: 339-342.

Pourcho, R. G., and D. J. Goebel (1986) A combined Golgi and autoradiographic study of $\left({ }^{3} \mathrm{H}\right)$ glycine-accumulating cone bipolar cells in the cat retina. Invest. Ophthalmol. Vis. Sci. Suppl. 27: 232.

Pourcho, R. G., and D. J. Goebel (1987) A combined Golgi and autoradiographic study of ${ }^{3} \mathrm{H}$-glycine-accumulating cone bipolar cells in the cat retina. J. Neurosci. 7: 1178-1188.

Pourcho, R. G., D. J. Goebel, and J. S. McReynolds (1984) Autoradiographic studies of $\left({ }^{3} \mathrm{H}\right)$-glycine, $\left({ }^{3} \mathrm{H}\right)$-GABA, and $\left({ }^{3} \mathrm{H}\right)$-muscimol uptake in the mudpuppy retina. Exp. Eye Res. 39: 69-81.

Seguela, P., M. Geffard, R. M. Buijs, and M. Le Moal (1984) Antibodies against GABA: Specific studies and immunocytochemical results. Proc. Natl. Acad. Sci. USA 81: 3888-3892.

Sterling, P. (1983) Microcircuitry of the cat retina. Annu. Rev. Neurosci. 6: 149-185.

Storm-Mathisen, J., A. K. Leknes, A. T. Bore, J. L. Vaaland, P. Edminson, F.-M.S. Haug, and O. P. Ottersen (1983) First visualization of glutamate and GABA in neurones by immunocytochemistry. $\mathrm{Na}$ ture 301: 517-520.

Voaden, M. J. (1976) Gamma-aminobutyric acid and glycine as retinal neurotransmitters. In Transmitters in the Visual Process, S. L. Bonting, ed., pp. 107-125, Pergamon, Oxford.

Wässle, H., I. Schäfer-Trenkler, and T. Voigt (1986) Analysis of a glycinergic inhibitory pathway in the cat retina. J. Neurosci. 6: 594 604. 